\title{
Fulminant Hepatic Failure in Murine Hepatitis Virus Strain 3 Infection: Tissue-Specific Expression of a Novel fgl2 Prothrombinase
}

\author{
J. W. DING,${ }^{1}$ Q. NING,${ }^{1}$ M. F. LIU,${ }^{1}$ A. LAI,${ }^{1}$ J. LEIBOWITZ, ${ }^{2}$ K. M. PELTEKIAN,${ }^{3}$ E. H. COLE ${ }^{1}$ \\ L. S. FUNG, ${ }^{1}$ C. HOLLOWAY, ${ }^{4}$ P. A. MARSDEN, ${ }^{1,5}$ H. YEGER, ${ }^{6}$ \\ M. JAMES PHILLIPS, ${ }^{1,6}$ AND GARY A. LEVY ${ }^{1 *}$ \\ Multi-Organ Transplant Program and Departments of Medicine and Pathology, Toronto Hospital, ${ }^{1}$ Department of \\ Surgery, Women's College Hospital, ${ }^{4}$ Department of Pediatric Laboratory Medicine, The Hospital for \\ Sick Children, ${ }^{6}$ and Department of Medicine, Division of Nephrology at St Michael's Hospital, ${ }^{5}$ University of \\ Toronto, Toronto, Ontario, and Department of Medicine, Dalhousie University, Halifax, Nova Scotia, ${ }^{3}$ Canada, \\ and Department of Pathology, Texas A\& M University, College Station, Texas ${ }^{2}$
}

Received 21 April 1997/Accepted 22 August 1997

\begin{abstract}
Activation of the immune coagulation system has been implicated in the pathogenesis of fulminant liver failure caused by murine hepatitis virus strain 3 (MHV-3). The recent discovery of the $f g l 2$ gene, which encodes for MHV-3-induced prothrombinase ( $g$ l2 2 prothrombinase), allows for fundamental studies to determine the molecular basis for fulminant liver failure. Transcription of the $f g l 2$ gene and translation of the protein it encodes were examined in the liver and other organs of susceptible mice following MHV-3 infection. No constitutive expression of the $f g l 2$ gene or the $f g l 2$ prothrombinase was detected. Within 12 to $24 \mathrm{~h}$ of MHV-3 infection, however, $f g l 2$ gene transcripts were detected in large amounts in the liver, spleen, and lungs, all of which are rich in reticuloendothelial cells, but were only focally present in small amounts in the kidney and brain. There was sequential detection of $f g l 2$ prothrombinase in the liver, where it was localized specifically to the endothelium of intrahepatic veins and hepatic sinusoids; this was allowed by fibrin deposition, which resulted in confluent hepatocellular necrosis. These results provide further evidence for the role of the selective expression of this novel $f g l 2$ prothrombinase in the pathogenesis of MHV-3-induced fulminant liver failure.
\end{abstract}

Fibrin deposition is fundamental to pathogenesis in a number of animal models of liver injury, including that from carbon tetrachloride, endotoxin, galactosamine, acetaminophen (paracetamol), and murine hepatitis virus strain 3 (MHV-3) (23). In the hepatocellular necrosis associated with these pathological processes, resident macrophages within the liver (Kupffer cells) exhibit morphological features of activation and release inflammatory mediators, including procoagulants, tumor necrosis factor alpha (TNF- $\alpha$ ), interleukin-1 (IL-1), proteolytic enzymes, and eicosanoids as well as superoxide anions and nitric oxide (12).

Studies from this laboratory have demonstrated a pivotal role for a procoagulant with prothrombin-cleaving activity (prothrombinase) in MHV-3-induced hepatic necrosis. Macrophages isolated from susceptible $(\mathrm{BALB} / \mathrm{c})$ but not from resistant $(\mathrm{A} / \mathrm{J})$ animals express large amounts of this prothrombinase in vitro and in vivo. Of great interest is that systemic inhibition of the prothrombinase with high-titer neutralizing monoclonal antibody prevents hepatic necrosis and prolongs survival in MHV-3-susceptible mice (15). These observations define a unique interface between immune-mediated coagulation and the acute inflammatory disease fulminant hepatitis. Recently, this laboratory reported the isolation and functional expression of complementary DNA clones for this prothrombinase, termed $f g l 2$ (20). The molecular clone corresponded to a mouse fibrinogen-like protein $(7,10)$. Examination of the predicted protein structure showed $36 \%$ sequence similarity

* Corresponding author. Mailing address: Toronto General Hospital, 621 University Ave., NU-10-151, Toronto, Ontario, Canada M5G2C4. Phone: (416) 340-5166. Fax: (416) 340-3492. E-mail: fg12 @msn.com. with the C-terminal portion of the beta and gamma subunits of fibrinogen, similar to other members of the fibrinogen family of proteins (10). When the entire coding region was expressed by a coupled vaccinia virus-bacteriophage system in RAW 264.7 cells, a marked expression of prothrombinase activity was observed (20). Therefore, the gene $f g l 2$ encoded a specific prothrombinase involved in the pathogenesis of MHV-3 infection. The murine gene for the $f g l 2$ prothrombinase was localized to proximal regions of mouse chromosome $5(20,25)$. We and others have shown that MHV-3 replicates in many tissues, including lung, bowel, brain, kidney, and spleen, in addition to the liver, and yet disease as defined by fibrin deposition and cellular necrosis is confined to the liver $(11,16)$. The present study demonstrates that following MHV-3 infection of susceptible BALB/c mice, $f g l 2 \mathrm{mRNA}$ transcripts are strongly induced in macrophage-rich organs, such as the liver, spleen, and lungs; however, immunoreactive $f g l 2$ ( $f g l 2$ prothrombinase) was expressed only in the liver. Furthermore, both $f g l 2$ mRNA transcripts and $f g l 2$ prothrombinase were expressed only by Kupffer cells and endothelial cells and not by hepatocytes of the liver after MHV-3 infection. The expression of the $f g l 2$ prothrombinase was promptly followed by fibrin deposition and massive hepatic necrosis, hallmarks of fulminant liver disease.

\section{MATERIALS AND METHODS}

Mice. Female BALB/c mice, 8 weeks of age, were purchased from Jackson Laboratory (Bar Harbor, Maine), and were housed in the animal facility at the Toronto Hospital Research Institute, University of Toronto. Mice were kept in a controlled-temperature $\left(22^{\circ} \mathrm{C}\right)$ environment with 12-h light-dark cycles and were given access to standard chow (LabDiet; PMI Feeds, Inc., St. Louis, Mo.) and water ad libitum prior to and during the experiment. Animals acclimatized to laboratory conditions for 1 week prior to experiments and were handled strictly according to Guide to the Care and Use of Experimental Animals of the Canadian Council on Animal Care. 
Reagents. The reagents used in the experiments included RPMI 1640, guanidine isothiocyanate, guanidine hydrochloride, redistilled formamide, ethidium bromide, and Hanks' balanced salt solution (HBSS) (GIBCO BRL, Life Technologies, Grand Island, N.Y.); DNA grade agarose (Bio-Rad, Laboratories, Hercules, Calif.); sodium dodecyl sulfate (SDS) (ICN Biomedicals, Inc., Aurora, Ohio); formaldehyde solution (Mallinckrodt Specialty Chemicals Company, Paris, Ky.); salmon sperm DNA, diethylpyrocarbonate (DEPC), and metrizamide (Sigma Chemical Co., St. Louis, Mo.); thioglycolate (Difco Laboratories, Detroit, Mich.); collagenase B and DNase I (Boehringer Mannheim, Quebec, Canada); pronase (Calbiochem, La Jolla, Calif.); fetal calf serum (FCS) (Flow Laboratories, Mississauga, Ontario, Canada); and $\left[\alpha-{ }^{32} \mathrm{P}\right] \mathrm{dCTP}(3,000 \mathrm{Ci} / \mathrm{mmol})$ (Amersham, Oakville, Ontario, Canada).

Virus. MHV-3 was plaque purified on monolayers of DBT cells and was grown to a titer of $1.5 \times 10^{7}$ PFU per ml in 17 CL1 cells. Viral titers were determined on monolayers of L2 cells by a standard plaque assay as described elsewhere (11, 16).

Organ collection. The livers, spleens, lungs, kidneys, and brains were removed from $\mathrm{BALB} / \mathrm{c}$ mice at 2, 4, 6, 8, 16, 24, 36, and $48 \mathrm{~h}$ following intraperitoneal administration of MHV-3 ( $10^{5} \mathrm{PFU} /$ mouse); organs removed immediately after MHV-3 injection $(0 \mathrm{~h})$ were used as normal controls. The organs were embedded in a cryoprotectant (O.C.T compound; Miles Inc., Elkhart, Ind.) in cryomolds and snap frozen in liquid nitrogen. The organs removed $24 \mathrm{~h}$ after MHV-3 infection were fixed in $4 \%$ paraformaldehyde at room temperature. The fixed tissue blocks were then embedded in paraffin and sectioned. The frozen organs were kept in a $-80^{\circ} \mathrm{C}$ freezer until RNA extraction, viral titration, or cryosection for immunohistochemical staining.

Histological examination of organs after MHV-3 infection. Histological sections of the liver, spleen, lungs, kidneys, and brain were prepared. The tissues were cut into 1 -by $0.2-\mathrm{cm}$ blocks and were fixed with $10 \%$ formalin in $0.1 \mathrm{M}$ phosphate balanced solution (PBS) ( $\mathrm{pH} 7.4$ ) at the beginning of the experiment and 24,36 , and $48 \mathrm{~h}$ following MHV-3 infection. The tissues were dehydrated in graded alcohol solutions and xylene and embedded in paraffin, and $4-\mu \mathrm{m}$ sections were cut and stained with hematoxylin and eosin (1).

Titration of virus in the organs. Samples of liver, spleen, lungs, kidneys, and brain were obtained $24 \mathrm{~h}$ after MHV-3 infection. Approximately $100 \mathrm{mg}$ of each frozen $\left(-70^{\circ} \mathrm{C}\right)$ organ was homogenized in RPMI 1640 supplemented with $2 \%$ FCS and $4 \mathrm{mM}$ glutamine as a $10 \%$ homogenate at $4^{\circ} \mathrm{C}$, and viral titers were then determined on L2 cell monolayers by a standard plaque assay as described previously $(11,16)$

Peritoneal macrophages. Peritoneal macrophages from BALB/c mice were harvested 4 days after intraperitoneal injection of $1.5 \mathrm{ml}$ of $3 \%$ thioglycolate as described previously (13). Macrophages were resuspended at a concentration of $10^{6} / \mathrm{ml}$ in RPMI 1640 containing $2 \mathrm{mM}$ glutamine. Macrophages represented a homogeneous population greater than $95 \%$ in purity as determined by morphology, nonspecific esterase staining, and staining with Mac-1 antibody (4).

Extraction of total RNA from macrophages. Peritoneal macrophages were infected with MHV-3 (multiplicity of infection = 5) and washed free of virus, and total RNA was extracted as described previously (5) with minor modifications. Briefly, macrophages were lysed in $8 \mathrm{M}$ guanidine hydrochloride and sheared with a 25-gauge needle. The lysate was centrifuged at $14,000 \mathrm{rpm}$ and $4^{\circ} \mathrm{C}$ for 30 min (Eppendorf centrifuge 5402; Netheler-Hinz GmbH, Hamburg, Germany). The supernatant was mixed with half the volume of $100 \%$ ethanol and allowed to precipitate at $-20^{\circ} \mathrm{C}$ for $40 \mathrm{~min}$, followed by centrifugation at $14,000 \mathrm{rpm}$ at $4^{\circ} \mathrm{C}$ for $30 \mathrm{~min}$. The pellet was redissolved in $8 \mathrm{M}$ guanidine hydrochloride and then mixed with half the volume of $100 \%$ ethanol for an additional $40 \mathrm{~min}$ at $-20^{\circ} \mathrm{C}$. Total RNA was pelleted by centrifugation at $14,000 \mathrm{rpm}$ at $4^{\circ} \mathrm{C}$ for 30 min. The RNA pellet was then washed with $70 \%$ ethanol repeatedly, vacuum dried, and resuspended in DEPC-treated water. Total cellular RNA from MHV-3 infected BALB/c macrophages was used as a positive control for $f g l 2$ mRNA transcript expression.

Isolation of murine nonparenchymal and parenchymal cells of the liver. To identify which cell populations in the liver (nonparenchymal or parenchymal cells) expressed $f g l 2$ mRNA transcripts after MHV-3 infection, nonparenchymal and parenchymal cells were isolated from normal liver or from the liver $24 \mathrm{~h}$ after intraperitoneal administration of MHV-3 ( $10^{5} \mathrm{PFU} /$ mouse). This method has been described previously $(9,27)$. Briefly, mice were anesthetized by intraperitoneal injection of sodium pentobartibal (5 mg/100 g of body weight) (Somnotol; MTC Pharmaceuticals, Cambridge, Ontario, Canada). The abdomen was opened by midline incision, and the portal vein was exposed and cannulated with silastic tubing (outer diameter, 0.037 in.; inner diameter, 0.020 in.) (Dow Corning, Midland, Mich.). The liver was perfused with oxygenated $\left(95 \% \mathrm{O}_{2}\right.$ and $\left.5 \% \mathrm{CO}_{2}\right)$ calcium- and magnesium-free HBSS at flow rate of $10 \mathrm{ml} / \mathrm{min}$ with a peristaltic pump (Dig-Staltic; Cole-Parmer Instrument Co., Barrington, Ill.) at $37^{\circ} \mathrm{C}$ for 10 min. The perfusate was changed to HBSS with calcium, magnesium, $0.02 \%$ collagenase B, and $0.001 \%$ DNase I for a further $10 \mathrm{~min}$. The liver was then removed and placed in a sterile petri dish containing cold $\left(4^{\circ} \mathrm{C}\right) \mathrm{HBSS}$ with $10 \%$ FCS, in which the liver capsule and attached cells were removed. The cellular suspension was then centrifuged at $50 \times g$ at $4^{\circ} \mathrm{C}$ for 2 min twice after being passed through a sterile steel cell sieve (60 mesh; Sigma Chemical Co.), and the supernatant was transferred to a siliconized bottle containing $0.5 \mathrm{mM} \mathrm{CaCl}$, followed by incubation with $0.02 \%$ pronase and $0.01 \%$ DNase I at $37^{\circ} \mathrm{C}$ for 60 min. The cellular pellets were resuspended in $10 \mathrm{ml}$ of HBSS after centrifugation at $400 \times g$ at $4^{\circ} \mathrm{C}$ for $7 \mathrm{~min}$, and $5 \mathrm{ml}$ of the cell suspension was mixed with $7 \mathrm{ml}$ of $30 \%$ metrizamide, followed by centrifugation at $1,620 \times g$ at $4^{\circ} \mathrm{C}$ for $15 \mathrm{~min}$. The nonparenchymal cell band was collected and washed free of metrizamide with HBSS, and the cell pellet was snap frozen with liquid nitrogen and stored at $-80^{\circ} \mathrm{C}$ until total RNA extraction.

Extraction of total RNA from tissue. The method of extraction of total RNA from tissue has been described elsewhere (26). In brief, $100 \mathrm{mg}$ of tissue was homogenized in a denaturing solution containing $4 \mathrm{M}$ guanidine isothiocyanate, $25 \mathrm{mM}$ sodium citrate, $0.1 \mathrm{M} 2$-mercaptoethanol, and $0.5 \% \mathrm{~N}$-lauroylsarcosine. The homogenate was then mixed with $2 \mathrm{M}$ sodium acetate $(\mathrm{pH} 4.0)$, watersaturated phenol, and chloroform-isoamyl alcohol (49:1) and incubated on ice for $15 \mathrm{~min}$. The mixture was centrifuged at $15,800 \times g$ at $4^{\circ} \mathrm{C}$ for $20 \mathrm{~min}$. The upper aqueous phase was transferred to a fresh tube and then mixed with an equal volume of $100 \%$ isopropanol and precipitated at $-20^{\circ} \mathrm{C}$ for $30 \mathrm{~min}$. RNA was pelleted by centrifugation at $15,800 \times g$ at $4^{\circ} \mathrm{C}$ for $30 \mathrm{~min}$ and then dissolved in the denaturing solution, to which an equal volume of $100 \%$ isopropanol was added for reprecipitation of RNA at $-20^{\circ} \mathrm{C}$. After centrifugation, the RNA pellet was washed with $75 \%$ ethanol twice, dried in vacuum, and resuspended in DEPC-treated water.

Northern blot analysis. Both macrophage $(15 \mu \mathrm{g})$ and tissue $(80 \mu \mathrm{g})$ total cellular RNAs were electrophoresed in a $1 \%$ denaturing agarose gel with $1.7 \%$ formaldehyde and then transferred to nitrocellulose membranes (Schleicher \& Schuell, Keene, N.H.) in $20 \times \mathrm{SSC}(1 \times \mathrm{SSC}$ is $0.15 \mathrm{M} \mathrm{NaCl}$ plus $0.015 \mathrm{M}$ sodium citrate). RNA was immobilized by baking the membrane at $80^{\circ} \mathrm{C}$ for $2 \mathrm{~h}$ in vacuum and was hybridized in $50 \%$ formamide $-5 \times$ SSPE $(1 \times$ SSPE is $0.18 \mathrm{M}$ $\mathrm{NaCl}, 10 \mathrm{mM} \mathrm{NaH}_{2} \mathrm{PO}_{4}$, and $1 \mathrm{mM}$ EDTA [pH 7.7]) $-5 \times$ Denhardt's solution$0.5 \%$ SDS-100 $\mu \mathrm{g}$ of denatured salmon sperm DNA per ml at $42^{\circ} \mathrm{C}$ for $18 \mathrm{~h}$ with a $\left[\alpha{ }^{32} \mathrm{P}\right] \mathrm{dCTP}$-labeled 1.2-kb DNA probe of murine $f g l 2 \mathrm{cDNA}\left(7 \times 10^{8} \mathrm{cpm} /\right.$ $\mu \mathrm{g}$ ) encompassing nucleotides 861 (ATGGGTGGA ...) to 2084 (... CTTACTG) as reported by Parr et al. (20). Labeled human glyceraldehyde-3phosphate dehydrogenase (GAPDH) cDNA was used to ensure equal loading of RNA. The membrane was washed with $1 \times$ SSPE and $0.1 \%$ SDS at room temperature for $15 \mathrm{~min}$ and then autoradiographed by exposure to Kodak film (X-OMAT; Eastman Kodak Company, Rochester, N.Y.)

In situ hybridization. The method used here has been described previously (31). Digoxigenin-11-UTP (Dig-UTP) (Boehringer Mannheim, Quebec, Canada)-labeled cRNA probes (antisense and sense) were synthesized with T7 and T3 RNA polymerases following subcloning of a 650-bp fragment of $f g l 2 \mathrm{cDNA}$, representing nucleotides 846 (TGTGACA ...) to 1495 (... ATGAATC) (20), into the EcoRI site of pBluescript (Stratagene, La Jolla, Calif.). The Dig-UTPlabeled probe concentration was determined by immunoenzymatic reaction with chemiluminescent detection, and the probes were stored at $-80^{\circ} \mathrm{C}$. Tissue sections were deparaffinized in $100 \%$ xylene and $100 \%$ alcohol, followed by prehybridization in $50 \%$ formamide and $2 \times \mathrm{SSC}$ at room temperature for $1 \mathrm{~h}$. The hybridization mixture consisted of $50 \%$ deionized formamide, $5 \%$ dextran sulfate, $250 \mu \mathrm{g}$ of salmon sperm DNA per ml, and $2 \mu \mathrm{g}$ of Dig-labeled cRNA probe per $\mathrm{ml}$ in $2 \times \mathrm{SSC}$. The hybridization mixture with the probe was denatured by heating in an $85^{\circ} \mathrm{C}$ water bath for $5 \mathrm{~min}$, chilled on ice for $1 \mathrm{~min}$, and added to tissue sections for hybridization at $42^{\circ} \mathrm{C}$ overnight. Posthybridization washing in a series of dilutions of SSC was followed by application of $3 \%$ blocking reagent at room temperature for $30 \mathrm{~min}$. After a brief wash in Tris- $\mathrm{HCl}$ buffer $(\mathrm{pH} 7.5)$, sections were incubated with polyclonal anti-Dig Fab fragments, conjugated to alkaline phosphatase (Boehringer Manheim), diluted 1:500 in Tris- $\mathrm{HCl}$ buffer. Unbound antibody was removed by two 5 -min washes with Tris-HCl buffer. A purple reaction product developed when alkaline phosphatase substrates, 5bromo-4-chloro-3-indolyl-phosphate (BCIP) and nitroblue tetrazolium (NBT), were applied to sections at room temperature for $120 \mathrm{~min}$. Sections were counterstained with methylene green and mounted in Permount for viewing.

Immunohistochemical staining. (i) Immunofluoresence for detection of the fgl 2 prothrombinase. In order to determine whether fgl2 prothrombinase immunoreactivity was expressed in the organs where fgl2 mRNA transcripts were evident following MHV-3 infection, immunohistochemical staining of various organs was performed with a rabbit polyclonal antibody made against the $f g l 2$ prothrombinase. Snap-frozen tissue specimens were cryosectioned at $6-\mu \mathrm{m}$ thickness and mounted on glass slides. Tissue slices were fixed with $100 \%$ methanol at $4^{\circ} \mathrm{C}$ for $5 \mathrm{~min}$ and air dried. They were rehydrated with $0.1 \mathrm{M}$ PBS (pH 7.4) and blocked with $10 \%$ normal horse serum in PBS at room temperature for $2 \mathrm{~h}$. An affinity-purified polyclonal antibody to the murine $f g l 2$ prothrombinase was produced in rabbits by repeated injections with a 14-amino-acid hydrophilic peptide (CKLQADDHRDPGGN) from exon 1 of the $f g l 2$ prothrombinase which had been coupled to keyhole limpet hemocyanin. Tissue slices were first incubated with antibody $(30 \mu \mathrm{g} / \mathrm{ml}$ in PBS) at room temperature for $2 \mathrm{~h}$ and then incubated with fluorescein isothiocyanate-conjugated goat immunoglobulin $\mathrm{G}$ (IgG) $(6.7 \mu \mathrm{g} / \mathrm{ml})$ fraction to rabbit IgG Fc (Cappel Laboratories, Durham, N.C.) at room temperature for $1 \mathrm{~h}$, following which they were washed five times in PBS with $0.05 \%$ Tween 20 . Tissue slices were then air dried, mounted with $90 \%$ glycerol, and photographed with a Leitz Laborlux fluorescence S microscope (Ernst Leitz Wetzlar GmbH, Wetzlar, Germany)

(ii) Immunoperoxidase staining of fibrin. Liver tissue from $\mathrm{BALB} / \mathrm{c}$ mice obtained at $0,24,36$, and $48 \mathrm{~h}$ after MHV-3 infection was examined for the presence of fibrin. The primary antibody used was a rabbit anti-human fibrinogen, a purified immunoglobulin fraction of rabbit antiserum (DAKO, Carpinte- 


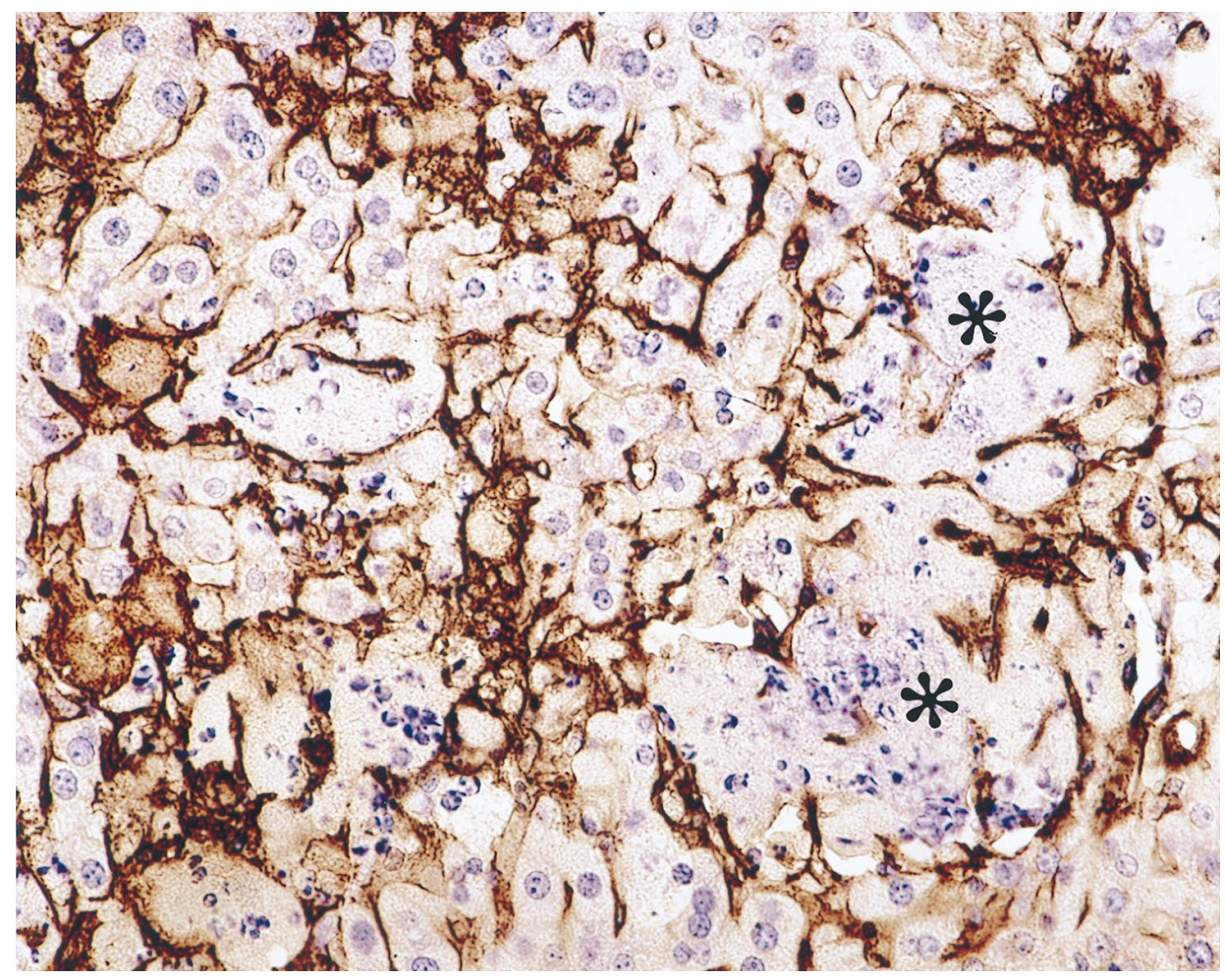

FIG. 1. BALB/c mouse liver at $48 \mathrm{~h}$ after MHV-3 infection. Confluent hepatocellular necrosis of liver parenchyma is shown (*). Necrotic cells show nuclear karyorrhexis, loss of cell membranes, and granular disintegration of cell cytoplasm. Fibrin is present as thin strands in the sinusoids (arrowheads). The nonnecrotic hepatocytes appear histologically normal. Hematoxylin-and-eosin stain was used. Magnification, $\times 300$.

ria, Calif.). The antibody is known to react with native human fibrinogen as well as with the fibrinogens of other species and with fibrin in human tissues and in the mouse. The technique utilized for detection of fibrin was the standard avidin-biotin complex method. The biotinylated secondary antibody was antirabbit IgG linked to peroxidase reacted with $3,3^{\prime}$-diaminobenzidine chromagen, followed by counterstaining with hematoxylin. Serial sections were stained with hematoxylin and eosin.

Statistical analysis. Quantitative data were expressed as means \pm standard deviations. Statistical analysis was carried out by using one-way analysis of variance, and a $P$ value of less than 0.05 was considered statistically significant.

\section{RESULTS}

Histology. Tissues, including liver, spleen, lungs, kidneys, and brain, from mice after MHV-3 infection were examined as described above. Histopathological changes were found only in the liver and not in the other organs examined. At $24 \mathrm{~h}$ postinfection, numerous small, discrete nonzonal foci of necrosis with a sparse polymorphonuclear leukocyte infiltrate could be seen in livers from BALB/c mice. At $48 \mathrm{~h}$, these lesions became larger, more numerous, and frequently panlobular, and there was early confluent necrosis (Fig. 1). Fibrin deposition was present but was difficult to recognize (see Fig. 7).

Viral titers in the organs after MHV-3 infection. High titers of virus were found in all tissues examined. The viral titers in the liver detected $24 \mathrm{~h}$ following MHV-3 infection were significantly higher than those in the lungs, kidneys, and brain $(P<$ $0.001)$, but there was no difference in viral titers between liver and spleen $(P>0.05)$ (Fig. 2).

Effect of MHV-3 on steady-state $f g l 2$ mRNA transcripts in murine tissues. Northern blot analysis of total cellular RNAs extracted from uninfected and infected organs at various time points after intraperitoneal administration of MHV-3 is shown in Fig. 3. The mRNA for $f g l 2$ was not constitutively expressed in the tissues examined in this study. In the liver, fgl 2 mRNA transcripts were detected at $8 \mathrm{~h}$ and persisted to $48 \mathrm{~h}$, the last time point studied, after MHV-3 injection (Fig. 3A). Similarly, mRNA transcripts for $f g l 2$ were first detected at $6 \mathrm{~h}$ in the spleen (Fig. 3B) and lungs (Fig. 3C) and persisted for $48 \mathrm{~h}$ after MHV-3 infection. In these organs the mRNA transcripts were localized to macrophages and endothelial cells. Despite the presence of mRNA transcripts in the spleen, no $f g l 2$ prothrombinase (protein) was detected even at day 5 , just prior to death of the animals. After $48 \mathrm{~h}$, transcripts (mRNA) were not seen in these tissues. By Northern blot analysis, no constitutive or

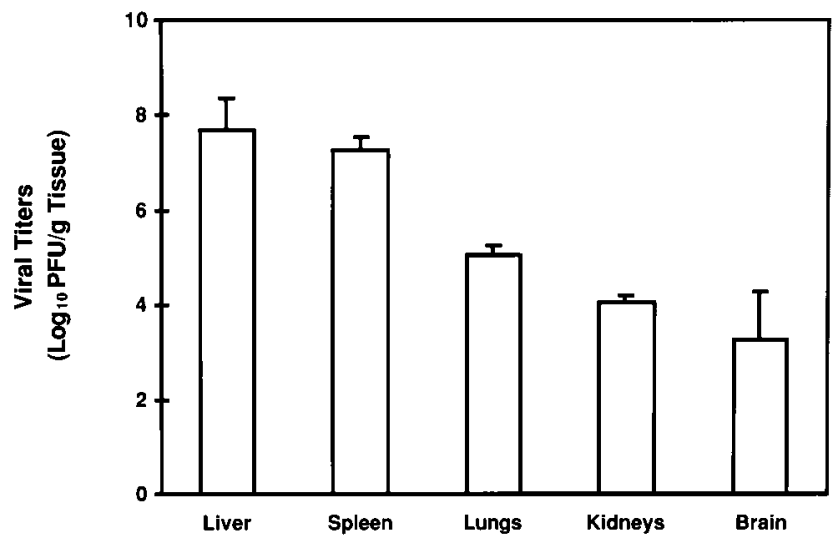

FIG. 2. Determination of viral titers in organs at $24 \mathrm{~h}$ following MHV-3 infection. The viral titer in the liver was significantly higher than those in the lung, kidney, and brain $(P<0.001)$ but did not differ significantly from that in the spleen $(P>0.05)$. Error bars indicate standard deviations. 


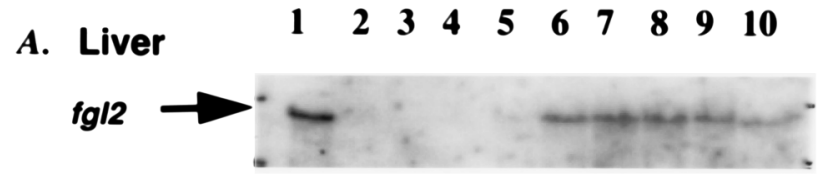

B. Spleen

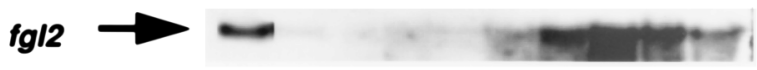

\section{Lungs}

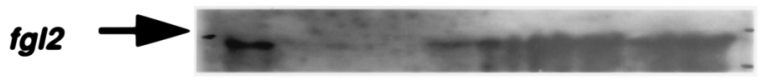

\section{Kidneys}

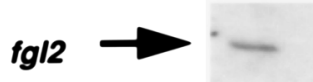

\section{E. Brain}

\section{fgl2}

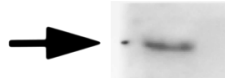

FIG. 3. Expression of $f g 12$ mRNA transcripts in tissue after MHV-3 infection. Eighty micrograms of total RNA was loaded in each well and hybridized with an fg12 cDNA. Lane 1, RNAs $(15 \mu \mathrm{g})$ from MHV-3-infected peritoneal macrophages (positive control); lane 2, RNAs, from organs immediately after MHV-3 infection (negative control); lanes 3 to 10: RNAs extracted 2, 4, 6, 8, 16, 24,36 , and $48 \mathrm{~h}$, respectively after MHV-3 infection. MHV-3-induced $f g 12$ mRNA transcription in the liver (A) started at $8 \mathrm{~h}$ and persisted to $48 \mathrm{~h}$, whereas expression of $f g 12$ mRNA transcripts was first detected at $6 \mathrm{~h}$ in the spleen (B) and lung $(\mathrm{C})$ and persisted for $48 \mathrm{~h}$. In contrast, $f g 12 \mathrm{mRNA}$ transcripts were not detected in the kidney (D) and brain (E) after MHV-3 infection. A GAPDH cDNA was used to ensure equal levels of mRNA in all lanes (data not shown).

MHV-3-induced mRNA transcripts of $f g l 2$ were seen in the kidney or brain at all time points studied (Fig. 3D and E).

fgl 2 mRNA expression in cellular subpopulations of the liver. In order to determine which cell subpopulations of the liver expressed $f g l 2$ transcripts after MHV-3 infection, parenchymal cells (hepatocytes) and nonparenchymal cells (Kupffer and endothelial cells) were isolated from liver. Total cellular RNAs extracted from both hepatocytes and nonparenchymal cells were analyzed by Northern blot analysis, which revealed that $f g l 2$ gene transcripts were expressed only in nonparenchymal cells (Fig. 4).

In situ hybridization. Liver tissue from uninfected BALB/c mice hybridized with an antisense or sense probe did not reveal constitutive $f g l 2$ mRNA expression (data not shown). In contrast, within $24 \mathrm{~h}$ of MHV-3 infection, fgl 2 mRNA transcripts were evident in endothelial cells and Kupffer cells in MHV-3infected BALB/c mice (Fig. 5). fgl2 mRNA expression was seen in splenic reticuloendothelial cells and macrophages and was also detected in bronchiolar cells, alveolar duct epithelial cells, and alveolar macrophages (data not shown). Low-level expression of $f g l 2$ was seen in the kidney and the brain following

\section{$\begin{array}{lllll}1 & 2 & 3 & 4 & 5\end{array}$}

fg/2

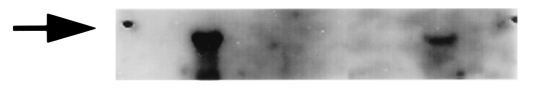

GAPDH

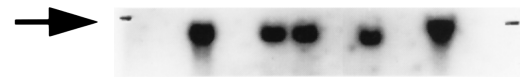

FIG. 4. Northern blot analysis of total cellular RNAs from both uninfected and infected hepatocytes and nonparenchymal cells at $24 \mathrm{~h}$ after MHV-3 infection. Lane 1, RNA from MHV-3-infected peritoneal macrophages (positive control); lanes 2 and 3, RNA from uninfected hepatocytes and nonparenchymal cells, respectively, lanes 4 and 5, RNA from hepatocytes and nonparenchymal cells, respectively, at $24 \mathrm{~h}$ after MHV-3 infection. Twenty micrograms of total RNA was added to each lane and hybridized with an $f g 12$ cDNA. A GAPDH cDNA was used to ensure equal levels of mRNA in all lanes.

MHV-3 infection (data not shown). In the brain, $f g l 2$ transcripts were found in subcortical neurons, and in the kidney, the $f g l 2$ transcripts were confined to the tubular epithelium of the inner medulla.

Immunohistochemical staining. Immunohistochemical staining of the liver for $f g l 2$ prothrombinase showed that it was not evident in normal controls (Fig. 6A) but was present only in the liver following MHV-3 infection, where it was first localized at $24 \mathrm{~h}$ postinfection to the sinusoids and large veins (Fig. 6B), but by $48 \mathrm{~h}$ it was seen in sinusoids and large confluent areas of hepatocellular necrosis (Fig. 6C). fgl2 prothrombinase increased until day 5 , when the animals died. fgl2 immunoreactivity was not detected in any other organs, including the spleen, lungs, kidneys, and brain, either constitutively or following MHV-3 infection (data not shown).

Sections of livers from $\mathrm{BALB} / \mathrm{c}$ mice examined at the onset of the experiments showed normal histology, and all were negative for fibrin. At $24 \mathrm{~h}$ after infection, the livers of BALB/c mice showed fibrin deposits in hepatic sinusoids; the deposits were randomly distributed as discrete microfoci throughout the liver. Occasionally, branches of intrahepatic veins also showed fibrin deposits. Hepatocytes appeared to be completely normal, except in widely scattered focal areas where liver cell necrosis was seen. In all instances, the necrosis was confined to areas where the fibrin deposits were most extensive and involved contiguous sinusoids. The necrotic hepatocytes showed complete karyorrhexis of nuclei, loss of cell membranes, and granular disintegration of cell structure, but hepatocytes elsewhere were normal. At $36 \mathrm{~h}$ these changes had progressed, and the focal fibrin deposits and focal necrosis pattern had changed to confluent areas of bridging necrosis and panlobular necrosis. By $48 \mathrm{~h}$, widespread multifocal areas of fibrin deposition and hepatocellular necrosis were evident, involving approximately $50 \%$ of the liver parenchyma. In every instance, the necrosis was associated with extensive fibrin deposits. No hepatocellular necrosis was seen in areas without fibrin deposition. The parenchyma in nonnecrotic areas still looked normal histologically. These studies showed a clear-cut progression of histopathological changes, beginning with discrete deposits of fibrin in sinusoids and progressing to larger areas of fibrin deposition accompanied by discrete foci of hepatocellular necrosis and finally to areas of confluent hepatic necrosis. In the larger areas of necrosis, fibrin was present throughout the lesions, and in some of them, neutrophils were present as well (Fig. 1 and 7). 


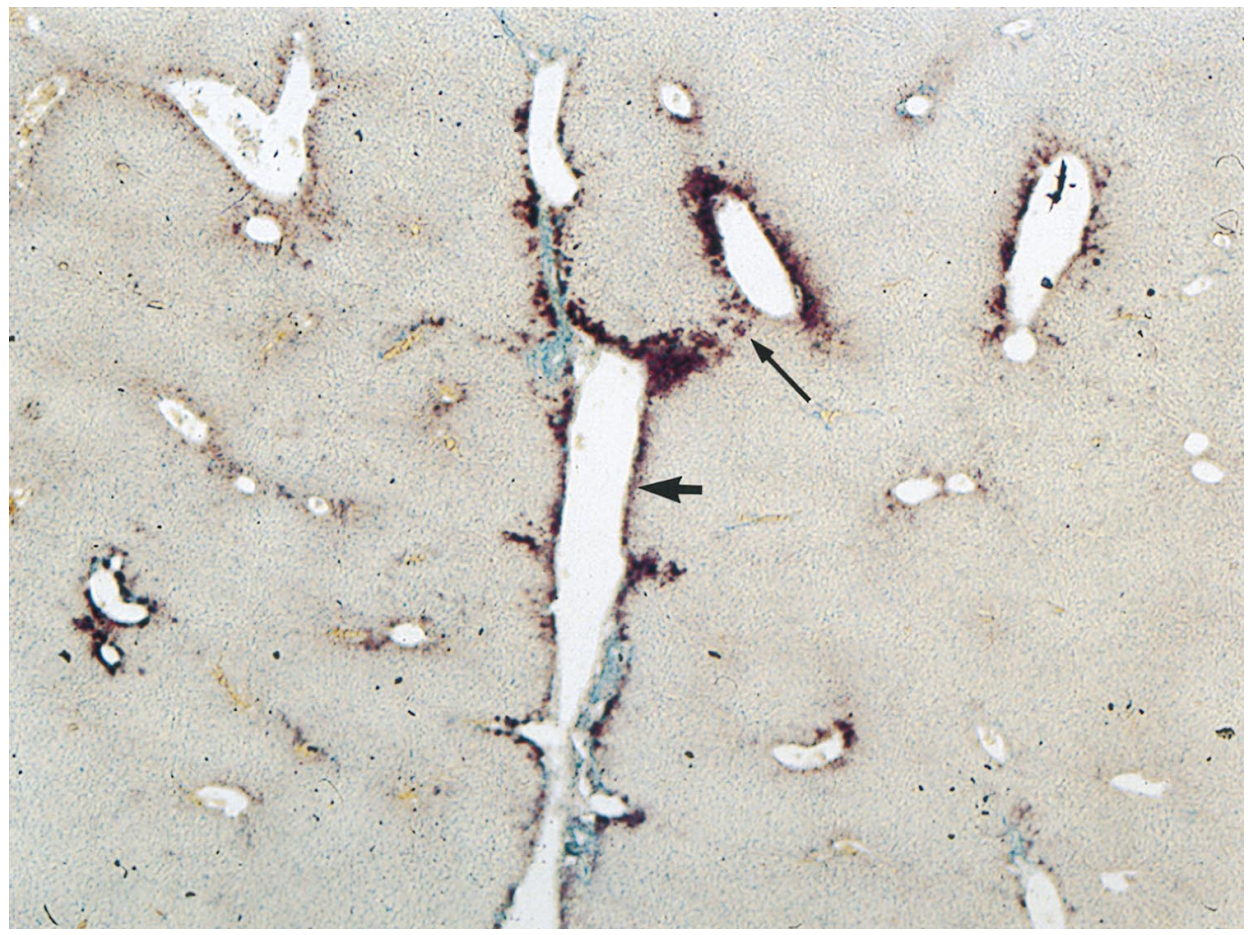

FIG. 5. In situ hybridization detection of $f g 12$ gene expression in the liver. $f g 12$ gene expression was detected by an antisense $f g 12$ probe, to detect sense mRNA. fg12 transcripts were found in endothelial cells of hepatic veins and sinusoids (thick arrow) and Kupffer cells (thin arrow) 24 h after MHV-3 infection. Hepatic parenchymal cells were negative. Alkaline phosphatase stain was used. Magnification, $\times 120$.

\section{DISCUSSION}

The recent molecular characterization of the fgl2 prothrombinase now allows for definitive studies to determine the cellular mechanisms involved in the pathogenesis of MHV-3induced fulminant hepatic failure. Within $8 \mathrm{~h}$ of MHV-3 infection, mRNA transcripts for the murine $f g l 2$ gene were evident in reticuloendothelial cells of the liver. Within 12 to $24 \mathrm{~h} \mathrm{MHV}-3$ infection, expression of the novel $\mathrm{fgl} 2$ prothrombinase immunoreactivity was detected in liver tissue from susceptible MHV-3-infected mice. The $f g l 2$ prothrombinase was seen in endothelial cells lining large veins, in the hepatic sinusoids, and in areas of focal necrosis. Shortly thereafter, and within $24 \mathrm{~h}$, focal deposits of fibrin were found in the liver sinusoids. By $48 \mathrm{~h}$, the fibrin deposits were extensive and were accompanied by multifocal confluent hepatocellular necrosis. Although by Northern blot analysis and in situ hybridization fgl 2 mRNA transcripts were detected in other organs, no translation product ( $f g l 2$ prothrombinase) or disease was seen outside the liver despite the presence of high viral titers. Supportive of this observation was the fact that functional prothrombinase activity was seen only in the liver at 18 hours, increasing to $72 \mathrm{~h}$ and remaining stable at high levels until day 5 , the time of death, whereas no such activity was seen in the lung or spleen at any time point.

MHV can produce a broad spectrum of diseases, including pneumonitis, encephalitis, enterocolitis, nephritis, and hepatitis (30). Although the virus replicates in all tissues, disease is not seen in tissues in which high viral titers are recovered, and the pattern of disease is organ specific. Data from our and other laboratories have suggested that host factors may be more critical than viral replication in the pathogenesis of MHV diseases $(8,23,32)$. Although in this and previous studies, replication of MHV-3 was significantly different in each organ examined, only in the liver is histopathology seen following MHV-3 infection. Thus, the fact that we saw large differences in viral replication in tissues in this study following MHV-3 infection was not unexpected and was consistent with other reports (8). Furthermore, the observation that the spleen and lungs were anatomically normal yet had high viral titers similar to those found in the liver supports the concept that viral replication alone will not explain MHV-3 disease.

Fibrin deposition in the liver is a unique feature of MHV3-induced fulminant liver failure, whereas infection of the brain with MHV-JAM results primarily in demyelination with no associated fibrin deposition $(3,6,8)$. Thus, the detection of mRNA transcripts in the lung, kidney, and brain following MHV-3 infection suggests that this gene may be involved in other MHV diseases. The short time course of MHV-3-induced fulminant hepatic necrosis may preclude development of disease in these organs.

It is well documented that MHV-3 disease is localized to the liver and that other organs are relatively spared (22). The fact that no $f g l 2$ prothrombinase was detected outside the liver was expected and was consistent with our hypothesis of the importance of this molecule in the MHV-3-induced liver disease. At this time, we cannot fully explain why translation of the $f g l 2$ gene does not occur in extrahepatic tissues, but this may reflect differences in rates of mRNA transcription, mRNA stabilities in different organs, and/or molecules that interfere with translation of the gene. These findings are consistent with our previous study in which mRNA transcripts for $f g l 2$ were evident in macrophages and liver tissue of resistant $\mathrm{A} / \mathrm{J}$ mice following MHV-3 infection (20). However, in this MHV-3-resistant strain, no $f g l 2$ immunoreactive prothrombinase or liver disease was seen (20).

Although by the molecular techniques employed it appears 

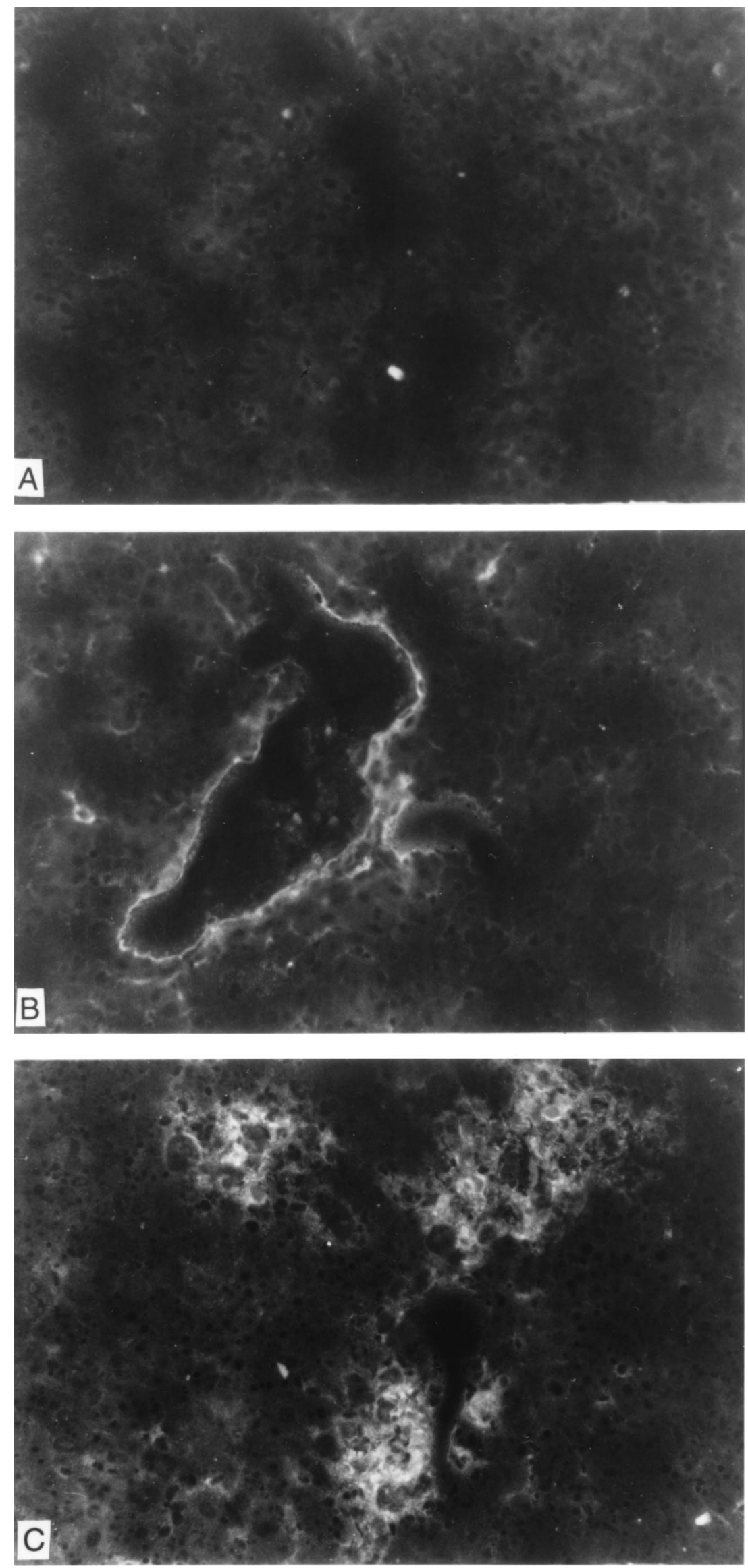

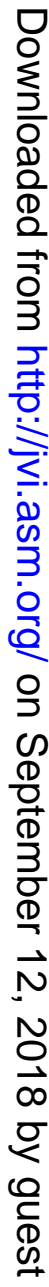


FIG. 6. Immunohistochemical staining of the liver after MHV-3 infection by using a rabbit polyclonal antibody against the fg12 prothrombinase. (A) Absence of staining in a normal control. Magnification, $\times 100$, (B and C) $f g 12$ prothrombinase was detected in the large veins and sinusoids (magnification, $\times 100)(B)$ and at $48 \mathrm{~h}$ in sinusoids and necrotic foci (magnification, $\times 400)(\mathrm{C})$ by immunofluorescence following MHV-3 infection.

that there are fewer steady-state $f g l 2$ mRNA transcripts in the liver than in other organs, this likely reflects the fact that no fgl2 mRNA transcripts are expressed either constitutively or following MHV-3 infection in hepatocytes, which constitute the major cell type of the liver. Northern analysis of subfractionated cells from the liver demonstrated high levels of $f g l 2$ mRNA transcripts only in reticuloendothelial cells of the liver.

Our observations are consistent with previous studies showing that the first abnormalities in the liver following MHV-3 infection, as observed by dynamic intravital microscopy, are disturbances of the liver microcirculation associated with sinusoidal microthrombosis (16). At no time was liver necrosis seen in the absence of fibrin. Thus, these findings firmly establish the importance of induction of the $f g l 2$ prothrombinase encoded by the $f g l 2$ gene in the pathogenesis of hepatocellular necrosis.

Our previous studies demonstrated that MHV-3 infection of macrophages resulted in transcription of a number of host inflammatory cytokines, including TNF- $\alpha$, IL-1, and superoxides (23). Cytokines can play a potent role in the course of inflammatory injury in vivo, and interference with their action can alter the courses of certain inflammatory diseases $(28,29)$. Treatment of rats with recombinant antibody to TNF has been shown to protect animals from hypotension, hypothermia, and mortality of gram-negative sepsis (21), and treatment of rabbits with an IL-1 receptor antagonist reduced mortality associated with endotoxin shock $(2,19)$. We have now shown that both
IL-1 and TNF- $\alpha$ directly induce endothelial cell transcription of $f g l 2$ (20). The importance of the $f g l 2$ prothrombinase in the pathogenesis of MHV-3 infection is further supported by the observation that a neutralizing antibody to this protein prevents fibrin deposition and protects mice from the lethality of MHV-3 infection (15).

The importance of the immune coagulation system resulting in fibrin deposition in human fulminant liver failure is controversial (14). Mori et al. have reported that fibrin is a classical feature of fulminant hepatitis $(17,18)$, but this has not been substantiated by others $(24,33)$. The reason for not finding fibrin in tissue sections may rest with the methodologies used. In routine hematoxylin-and-eosin-stained sections, fibrin is not easily recognized, and its presence is further obscured by hepatic necrosis. Even the use of special stains for fibrin is not always conclusive in our experience. However, by using recently available specific antibodies such as those used in this study, fibrin is clearly evident in the hepatic lesions of MHV3 -infected livers from susceptible mice. Because of these observations with MHV-3-infected mice, we have now reexamined liver tissue from patients with fulminant liver failure and have found fibrin deposits by using methodologies similar to those described in this report (unpublished data).

In conclusion, $f g l 2$ mRNA transcripts are seen in reticuloendothelial cell-rich organs, including liver, spleen, and lungs, following MHV-3 infection. However, $f g l 2$ prothrombinase immunoreactivity is evident only in the liver. The induction of this

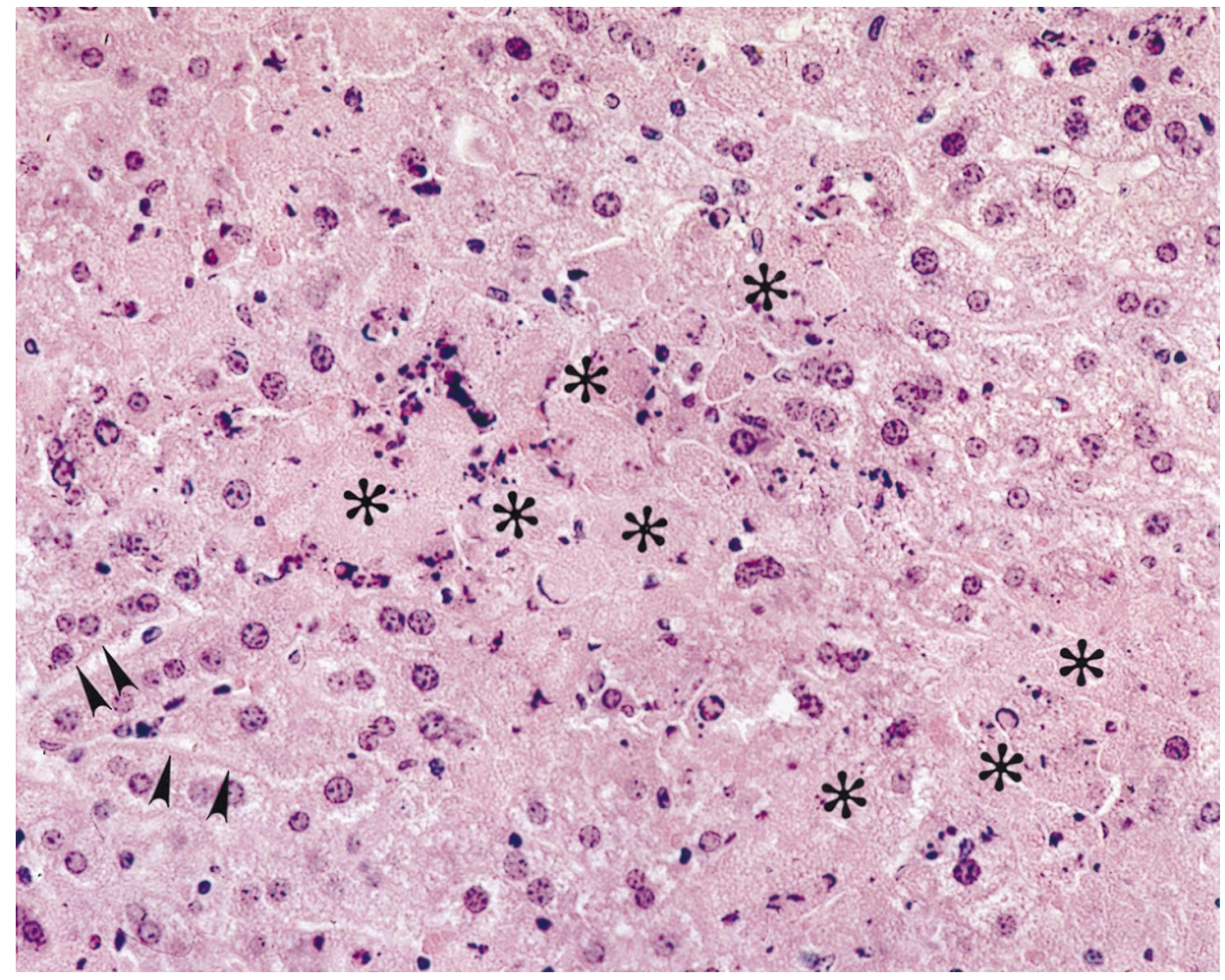

FIG. 7. Immunohistochemical staining of the liver for fibrin. Widespread fibrin deposition (brown) is seen in sinusoids, frequently outlining areas of hepatocellular necrosis $(*)$. Larger focal areas of fibrin deposition are also seen, with loss of liver cells. Immunoperoxidase stain was used. Magnification, $\times 400$. 
protein in the sinusoids and large portal veins initiates microthrombosis and fibrin deposition, which lead to perturbations in microvascular hemodynamics and subsequent liver cell necrosis. These studies firmly establish the pivotal role of $f g l 2$ and its protein product in the pathogenesis of fulminant liver failure caused by MHV-3.

\section{ACKNOWLEDGMENTS}

This work was supported by group grant PG 11810 from the Medical Research Council of Canada.

We are grateful to Charmaine Beal and Dawn Paluch for excellent secretarial assistance.

\section{REFERENCES}

1. Abecassis, M., J. A. Falk, L. Makowka, V. J. Dindzans, R. E. Falk, and G. A. Levy. 1987. 16,16-Dimethyl prostglandin $\mathrm{E}_{2}$ prevents the development of fulminant hepatitis and blocks the induction of monocyte/macrophage procoagulant activity after murine hepatitis virus strain 3 infection. J. Clin. Invest. 80:881-889.

2. Alexander, J. R., B. C. Sheppard, J. C. Jensen, H. Langstein, C. M. Buresh, D. Venzon, E. C. Walker, D. L. Fraker, M. C. Stovorff, and J. A. Norton. 1991.Treatment with recombinant human tumor necrosis factor-alpha protects rats against the lethality, hypotension and hypothermia of gram-negative sepsis. J. Clin. Invest. 88:34-39.

3. Buchmeier, M. J., H. A. Lewicki, P. J. Talbot, and R. L. Knobler. 1984 Murine hepatitis virus 4 (MHV-JHM) induced neurological disease is modulated in vivo by monoclonal antibody. Virology 132:261-270.

4. DeSouza, M. S., A. L. Smith, and K. Bottomly. 1991. Infection of Balb/cByJ mice with the JAM strain of mouse hepatitis virus alters in-vitro splenic T cell proliferation and cytokine production. Lab. Anim. Sci. 41:99-105.

5. Evans, R., and S. J. Kamdar. 1990. Stability of RNA isolated from macrophages depends on the removal of an RNA-degrading activity early in the extraction procedure. Biotechniques 8:357-360.

6. Fleming, J. O., R. A. Shubin, M. A. Sussman, N. Casteel, and S. A. Stohlman. 1989. Monoclonal antibodies to the matrix (E1) glycoprotein of mouse hepatitis virus protect mice from encephalitis. Virology 168:162-167.

7. Fung, L. S., G. Neil, J. Leibowitz, E. H. Cole, S. Chung, A. Crow, and G. A. Levy. 1991. Monoclonal antibody analysis of a unique macrophage procoagulant activity induced by murine hepatitis virus strain 3 infection. J. Biol. Chem. 266:1789-1795.

8. Houtman, J. J., and J. O. Fleming. 1996. Pathogenesis of mouse hepatitis virus-induced demyelination. J. Neurovirol. 2:361-270.

9. Janousek, J., E. Strmen, and F. Gervais. 1993. Purification of murine Kupffer cells by centrifugal elutriation. J. Immunol. Methods 164:109-117.

10. Koyama, S., L. R. Hall, H. G. Haser, S. Tonegawa, and H. Saito. 1987. Structure of a cytotoxic T-lymphocyte-specific gene shows a strong homology to fibrinogen $\beta$ and $\gamma$ chains. Proc. Natl. Acad. Sci. USA 84:1609-1613.

11. Lamontagne, L., and P. Jolicoeur. 1991. Mouse hepatitis virus 3-thymic cell interactions correlating with viral pathogenecity. J. Immunol. 146:3152-3159.

12. Laskin, D. L. 1990. Nonparenchymal cells and hepatotoxicity. Semin. Liver Dis. 10:293-304.

13. Levy, G. A., J. L. Leibowitz, and T. S. Edgington. 1981. The induction of monocyte procoagulant activity by murine hepatitis virus MHV-3 parallels disease susceptibility in mice. J. Exp. Med. 154:1150-1163.

14. Levy, G. A., H. Helin, and T. S. Edgington. 1984. The pathobiology of viral hepatitis and immunologic activation of the coagulation protease network.
Semin. Liver Dis. 4:59-68.

15. Li, C., L. S. Fung, A. Crow, N. Myers-Mason, M. J. Phillips, J. L. Leibowitz, E. Cole, C. A. Ottaway, and G. A. Levy. 1992. Monoclonal antiprothrombinase (3D4.3) prevents mortality from murine hepatitis virus (MHV-3) infection. J. Exp. Med. 176:689-697.

16. MacPhee, P. J., V. J. Dindans, L. S. Fung, J. L. Leibowitz, and G. A. Levy. 1985. Acute and chronic changes in the microcirculation of the liver in inbred strains of mice following infection with mouse hepatitis virus type 3. Hepatology 5:649-660.

17. Mori, W., and A. Naoto. 1981. Acute hepatic cell necrosis experimentally produced by viral agents in rabbits. Am. J. Pathol. 103:31-35.

18. Mori, W., J. Shiga, and H. Irie. 1986. Schwartzman reaction as a pathogenetic mechanism in fulminant hepatitis. Semin. Liver Dis. 6:267-269.

19. Ohlsson, K., P. Bjork, M. Bergenfeldt, R. Hageman, and R. C. Thompson. 1990. Interleukin-1 receptor antagonist reduces mortality from endotoxin shock. Nature (London) 348:550-552.

20. Parr, R. L., L. Fung, J. Reneker, N. Myers-Mason, J. L. Leibowitz, and G. A. Levy. 1995. Association of mouse fibrinogen-like protein with murine hepatitis virus-induced prothrombinase activity. J. Virol. 69:5033-5038.

21. Patton, J. S., P. M. Peters, J. McCable, D. Crase, S. Hansen, A. B. Chen, and D. Liggitt. 1987. Development of partial tolerance to the gastrointestinal effects of high doses of recombinant tumor necrosis factor-alpha in rodents. J. Clin. Invest. 80:1587-1596.

22. Piazza, M. 1969. Experimental viral hepatitis. p. 1-274. Charles C. Thomas, Springfield, Ill.

23. Pope, M., O. Rotstein, E. Cole, S. Sinclair, R. Parr, B. Cruz, R. Fingerote, S. Chung, R. Gorczynski, L. Fung, J. Leibowitz, U. S. Rao, and G. A. Levy. 1995. Pattern of disease after murine hepatitis virus strain 3 infection correlates with macrophage activation and not viral replication. J. Virol. 69:5252-5260.

24. Portmann, B., I. C. Talbot, D. W. Day, A. R. Davidson, I. M. Murray-Lyon, and R. Williams. 1975. Histopathological changes in the liver following a paracetamol overdose: correlation with clinical and biochemical parameters. J. Pathol. 117:169-181.

25. Qureshi, S. T., S. Clermont, J. L. Leibowitz, G. A. Levy, and D. Malo. 1995. Mouse hepatitis virus-3 induced prothrombinase (Fg12) maps to proximal chromosome 5. Genomics 29:307-309.

26. Ribaudo, R., M. Gilman, R. E. Kingston, P. Chomczynski, and N. Sacchi. 1991. Single-step RNA isolation from cultured cells or tissues, p. 10.11.710.11.14. In J. E. Coligan, A. M. Kruisbeek, D. H. Margulies, E. M. Shevach, and W. Strober (ed.), Current protocols in immunology, supplement 3. John Wiley \& Sons, Inc., New York, N.Y.

27. Seglen, P. O. 1973. Preparation of rat liver cells. Exp. Cell Res. 82:391-398.

28. Tracey, K. J., B. Beutler, S. F. Lowry, J. Merryweather, S. Wolpe, I. W. Milsark, R. J. Hariri, T. J. Fahey, A. Zentalla, J. D. Albert, et al. 1986. Shock and tissue injury induced by recombinant human cachectin. Science 234:470474.

29. Tracey, K. J., S. F. Lowry, T. J. Fahey, J. D. Albert, Y. Fong, D. Hesse, B. Beutler, K. R. Manogue, S. Calvano, H. Wei, et al. 1987. Cachectin/tumor necrosis factor induces lethal shock and stress hormone responses in the dog. Surg. Gynecol. Obstet. 106:415-422.

30. Tyrrell, D. A., J. D. Almeida, D. M. Berry, et al. 1968. Coronaviruses. Nature (London) 220:650-652.

31. Wang, D., H. Yeger, and E. Cutz. 1996. Expression of gastrin releasing peptide receptor gene in developing lung. Am. J. Respir. Cell Mol. Biol. 14:409-416.

32. Yuwaraj, S., M. Cattral, M. Pope, and G. A. Levy. 1996. Murine hepatitis virus: molecular biology and pathogenesis. Viral Hepatitis 2:125-142.

33. Zimmerman, H. J., and K. G. Ishak. 1982. Valproate-induced hepatic injury: analysis of 23 fatal cases. Hepatology 2:591-597. 


\title{
ERRATA
}

\author{
Attenuated Replication of Human Immunodeficiency Virus \\ Type 1 with a Didanosine-Selected Reverse \\ Transcriptase Mutation \\ PREM L. SHARMA AND CLYDE S. CRUMPACKER \\ Division of Infectious Disease, Beth Israel Deaconess Medical Center, and Department of \\ Medicine, Harvard Medical School, Boston, Massachusetts 02215
}

Volume 71, no. 11, p. 8850: Add the following sentence to the Acknowledgments: “Additional support was provided by NIH grants AI27659 and AI38858 and by training grant 5T32 AI07387."

\section{Fulminant Hepatic Failure in Murine Hepatitis Virus Strain 3 Infection: Tissue-Specific Expression of a Novel $f g l 2$ Prothrombinase \\ J. W. DING, Q. NING, M. F. LIU, A. LAI, J. LEIBOWITZ, K. M. PELTEKIAN, E. H. COLE, L. S. FUNG, C. HOLLOWAY, P. A. MARSDEN, H. YEGER, M. JAMES PHILLIPS, AND GARY A. LEVY \\ Multi-Organ Transplant Program and Departments of Medicine and Pathology, Toronto Hospital, Department of Surgery, Women's College Hospital, Department of Pediatric Laboratory Medicine, The Hospital for Sick Children, and Department of Medicine, Division of Nephrology at St Michael's Hospital, University of Toronto, Toronto, Ontario, and Department of Medicine, Dalhousie University, Halifax, Nova Scotia, Canada, and Department of Pathology, Texas A \& M University, College Station, Texas}

Volume 71, no. 12, p. 9225 and 9229: Figures 1 and 7 were transposed; the legends are correct. 